\title{
О ПРИРОДЕ МЕЛАНОИДИНОВЫХ ВЕЩЕСТВ, УЧАСТВОВАВШИХ В ПРОЦЕССЕ ОБРАЗОВАНИЯ КЕРОГЕНА ДИКТИОНЕМОВОГО СЛАНЦА
}

\section{Л. НАППА}

\author{
А. ФОМИНА, \\ доктор химических наук
}

Уже в начале второго десятилетия двадцатого века Майар $\left[{ }^{1-2}\right]$ обращал внимание углехимиков и почвоведов на то, что в образовании гумуса почв и вещества углей может играть значительную роль реакция меланоидинообразования, происходящая между аминокислотами и сахарами, а также между пептидами, полипептидами и сахарами с последующим образованием гуминоподобных веществ. Майар указывал [], что ксилоза и арабиноза реагируют с гликоколем мгновенно; фруктоза, галактоза, глюкоза и манноза - достаточно быстро; лактоза и мальтоза - медленнее; а сахароза не реагирует в течение многих часов - только после определенного времени начинается медленная реакция, которая, по мнению автора, возникает за счет продуктов ее рагпада. Характеризуя эту реакцию, Майар указывал, что она не требует ни окислителей, ни высоких температур и высоких давлений. Тем не менее длительное время многие углехимики не принимали во внимание этого важного открытия и исключали из углеобразователей продукты частичного распада белков и углеводов. Большее значение реакцин Майара в образовании почвенного гумуса придавали Эндерс [3] и др. K настоящему времени реакция меланоидинообразования в природных условиях экспериментально подтверждена в работах по изучению почвенного гумуса $[4,5]$, и - торфо- и сапропелеобразования [6].

Еще в 1938 г. В. А. Успенский [7] считал возможным объяснить высокое содержание азота в керогене диктионемового сланца образованием меланоидиновых веществ, возникших по реакции Майара за счет хитина, содержащегося в скелетах граптолитов. Однако, экспериментальных подтверждений этого предположения в то время еще не имелось.

С. М. Манская и др. [8] и Т. В. Дроздова $[9,10]$ в течение последнего десятилетия экспериментально подтвердили образование меланоидинов не только из аминокислот и сахаров, но и непосредственно из глюкозамина и хитина.

Изучение гидролизатов керогена диктионемового сланца, проведенное авторами настоящего исследования, показало, что в его состав также входят' аминокислоты али фатического и ароматического рядов ["1].

Проведенное затем исследование гидролизата органического вещества граптолитов Dictyonema flabelliforme, выделенных нз диктионемового сланца С. М. Манской и т. В. Дроздовой $\left[{ }^{12}\right]$, показало наличие в его составе почти всех аминокислот, ндентифнцированных из гидролизатов керогена диктионемового сланща, а также глюкозамина и глюкозы (?).

Авторам настоящего сообщения не удалось установить углеводы в продуктах гидролиза керогена диктионемового сланца, полученных при его обработке 6 н, соляной кислотой (при температуре $105^{\circ} \mathrm{C}$ в течение 24 час). Хотя в литературе имеются указания на то, что сахара могут быть обнаружены в растворе, вытекающем нз ко- 
лонки при очистке подобных гидролизатов аминокислот от минеральных солей на катионитах $\left[{ }^{13}\right]$. Отрицательный результат можно толковать двояко: либо сахара как таковые не присутствуют в веществе керогена, либо они успевают разложиться при гидролизе в сравнительно жестких условиях опыта. Последнее можно считать наңболее вероятным, так как глюкоза и некоторые другие углеводы при длительном нагревании уже с $12 \%$-ой $\mathrm{HCl}$ расщепляются, как это было обнаружено при определении уроновых кислот по Толленсу, и Лефевру $\left[{ }^{14}\right]$.

Поэтому для установления углеводов в веществе керогена диктионемового сланца были выбраны более мягкие, чем для получения аминокислот, условия гидролиза. С этой целью была проведена серия опытов ступенчатого гидролиза керогена $5 \%$-ной соляной кислотой. Полученные при этом гидролизаты использовались также и для идентификации глюкозамина.

Глюкозамин в качестве стандарта был получен из хитина панцирей раков по методике, описанной Ю. А. Ждановым и др. [15].

\section{Экспериментальная часть}

В качестве исходного материала использовался флотационный концентрат диктионемового сланца, содержащий 48,6\% керогена. Для ступенчатого гидролиза была

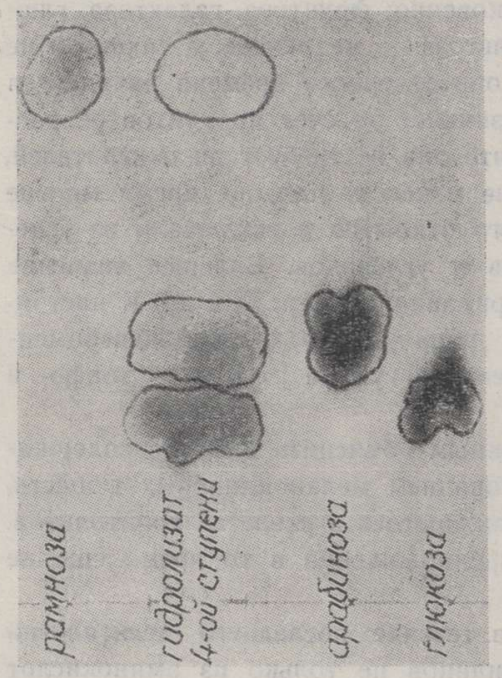

Рис. 1. Восходящая хроматография.

Растворитель: н-бутиловый спирт; ледяная уксусная кислота, вода. Проявитель: о-фталевая кислота и анилин в спирте. взята навеска концентрата, эквивалентная 253 с керогена. Гидролиз осуществлялся на кипящей водяной бане $5 \%$-ной соляной кислотой, взятой к керогену в отношении 5:1. Длительность каж дой ступени "гидролиза - 2 час. Bсего было проведено 4 ступени гидролиза, с суммарным временем 8 час. Продукты гидролиза каждой ступени собирались отдельно. Выделение и очистка нелетучих с водяным паром продуктов гидролиза производились по ранее описанной методике [11]. Водный раствор гидролизатов, вытекающий из колонки с катионитом КУ-2 (в $H$ форме) использовался для идентификации углеводов, а глюкозамин вместе с аминокислотами определялся из элюата. Для разделения и идентификации как углеводов, так и глюкозамина, использовалась бумажная хроматография.

В качестве растворителя применялась смесь н-бутанола, ледяной уксусной кислоты и бидистиллированной воды в соотношении $4: 1: 5\left[{ }^{16}\right]$. Проявителями для углеводов служили раствор $n$-аминофенола в спирте $\left[{ }^{17}\right]$, а также специфический реактив для идентификации гексоз к: пенто3, o-фталевая кислота и анилин в спирте [18].

В гидролизатах первой и второй ступеней (после 4 час) углеводы не были обнаружены. В гидролизате третьей ступени (после 6 час) была установлена только глюкоза и лишь в гидролизате четвертой ступени (суммарно после, 8 час) были идентифицированы глюкоза, арабиноза и, по-видимому, рамноза (рис. 1).

Для хроматографического анализа на глюкозамин в качестве растворителя применялась та же смесь, что н для углеводов. Проявнтелем служил 1\%-ный раствор нингидрина в ацетоне. 
В гидролизате первой ступени не оказался ни аминокислот, ни глюкозамина. В гидролизате второй ступени были обнаружены следы аминокнслот. В гидролизатах третьей и четвертой ступеней, наряду с аминокислотами, был установлен и глк)козамин (рис. 2).

\section{Обсуждение результатов}

Следует отметить, что ступенчатый гидролиз слабой соляной кислотой одновременно дополнительно подтвердил, что углеводы и аминокислоты не случайные примеси, а являются структурными элементами, органически входящими в кероген. Это подтверждается тем, что гидролизаты первых двух ступеней не содержали углеводов, а амннокислоты установлены только в виде следов в гидролизате второй ступени. Если бы они были в адсорбированном виде или слабо связанном состоянии, то они как хорошо растворимые в воде соединения, присутствовали бы уже в первом гидролизате.

Таким образом, смягчение условий гидролиза как по концентрации кислоты, так и по времени контакта с ней, позволило установить, что в керогене диктионемового сланца, помимо аминокислот и глюкозамина, присутствуют в качестве структурных элементов глюкоза, а также и другие сахара, встречающиеся в продуктах распада расти. тельных слизей $\left[{ }^{19}\right]$.

Палакас, Свейн и Смит $\left[{ }^{20}\right]$, исследовавшие гидролизаты битуминозных пород, от миоцена до ордовик: включительно, на присутствие сахаров ( $5 \%$-ной серной кислотой на кипящей водяной бане в течение 8-10 час), установили в трех образцах разных формаций ордовика глюкозу, е одном - галактозу (?), в одном (в двух под вопросом) - арабинозу и в двух образцах (в одном под вопросом) - ксилозу. Преобладающей во всех трех гидролизатах была лгокоза. Гертнер и Фишер $\left[{ }^{21}\right]$ идентифицировали в гидролизатах посидониевых сланцев целлобиозу, немного глюкозы и оксиметилфурфурол.

Ранее в гидролизатах керогена диктионемового сланца были идентифирированы 11 аминокислот, широко распространенных в протеинах животного и растительного мира: глицин, аланин, лейцин, изолейцин, валин, $\gamma$-аминомасляная кислота, серин, глутаминовая кислота, аргинин, пролин и фенилаланин $\left.{ }^{22}\right]$. Все эти соединения являются аминосодержащими компонентами, необходимыми для синтеза меланоидинов, также как

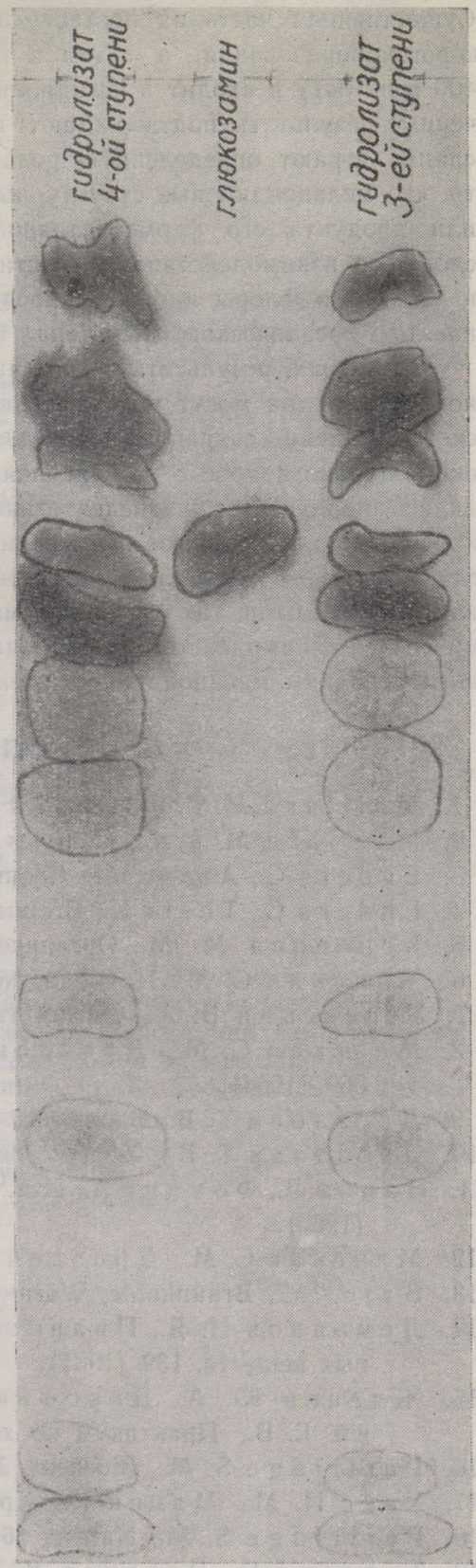

Рис. 2. Нисходящая хроматография.

Растворитель: ледяная уксусная кислота, вода. Проявитель: $1 \%$-ный раствор нингидрина. и продукт ферментативного или кислотного гидролиза хитина - глюкозамин. Идентифицированные моносахариды-глюкоза, арабиноза и рамноза являются вторым необходи- 
мым компонентом в реакции Майара. Эти моносахариды также широко распространены в природе, в том числе и в растительных слизях. Несомненно, не все аминокислоты и моносахариды, входяшие в вещество керогена, идентифицированы (остались неидентифицированные пятна). Часть их могла разложиться в процессе ступенчатого гидролиза. Существенная часть их претерпела структурные превращения в комилексе процессов керогенообразования, а затем в течение длительного пребывания в залежи (более 400 млн. лет) и входит в негидролизуемое органическое вещество- Тем не менее, полученные результаты подтверждают: во-первых, что в структуре керогена диктионемового сланца играют определенную роль вещества меланоидинового характера. Во-вторых, то, что меланоидиновые структурные элементы керогена возникли не только из хитина или продукта его ферментативного распада - глюкозамина, а в результате более сложного взаимодействия с участием продуктов ферментативного распада протеинов и углеводов флоры и фауны, послуживших источником для образования этого ископаемого органического полимера.

В-третьих, результаты указывают на то, что в определенных условиях меланоидиновые вещества могут пребывать в залежах в течение весьма длительного геологического времени, сохраняя исходные структурные элементы. Сейчас трудно решить окончательно вопрос о том, первичны ли аминокислоты и моносахариды, или они являлись продуктами жизнедеятельности микробов, перерабатывавших останки флоры и фауны. Но, в ресинтезе несомненно участвовал первичный продукт распада хитина глюкозамин - химическое соединение, которое в одинаковой мере могло реагировать как с первичными, так и вторичными соединениями, подчиняясь единственно закону химического взаимодействия, приводящему к образованию более устойчивых к окружающим условиям меланоидиновых веществ.

\section{ЛИТЕРАТ У Р А}

1. M a il1 a r d M. L. C., Comptes Rendus, 155, 1554 (1912); 156, 1159 (1913).

2. M a illa rd M. L. C., Comptes Rendus, 154, 66 (1912).

3. Enders C., Angewandte Chemie, 56, Nr. 41/42, 281 (1943).

4. Ender s C., The is K., Brennstoff-Chemie, 19, 360, 403, 439 (1938).

5. Коново в а М. М., Органическое вещество почвы, М., 1963.

6. М а н ск а я С. М., Природа, № 1, 26 (1957).

7. У спен ски й В. А., Химия твердого топлива, 9, 7 (1938).

8. М анская С. М., Дроздов а Т. В., Тобелко К. И., Докл. АН СССР, 96, 569 (1954).

9. Д розд ов а Т. В., Биохимия, 22, 487 (1957).

10. Д роз дов а Т. В., Успехи совр. биол., 47, 277 (1959).

11. Н а п п а Л., Ф о м и н А., Изв. АН ЭССР, Серия физ.-матем. и техн. наук, № 3,320 (1963).

12. М ан ск а я С. М., Д роз дов а Т. В., Геохимия, № 11, 953 (1962).

13. В a j or M., Braunkohle, Wärme und Energie, Nr. 10, 472 (1960).

14. Д е мьянов Н. Я., Прян ишн нков Н. Д., Общие приемы анализа растительных веществ, 139 (1934).

15. Жданов Ю. А., ДорофинкоГ. Н., КорольченкоГ. А., Богданов а Г. В., Практикум по химии углеводов, 62, Росвузиздат, 1963.

16. Partridge S. M., Biochem. J., 48, 238 (1948).

17. Х а й с И. М., М а цек К., .Хроматография на бумаге, М., 1962.

18. Partridge S. M., Nature, 164, 443 (1949).

19. Толленс Б., Эльснер К., Краткий справочник по химии углеводов, Л.-М., 1938.

20. P a la c a s, J., Swa in F., S m ith F., Nature, 185, 234 (1960).

21. G a e rtne r H. R., Fis che r K., Brennstoff-Chemie, 37, Nr. 21/22, 377 (1956).

22. Фомин а А., Н а п п а Л., Геохимия, № 2, 163 (1964). 


\title{
DIKTUONEEMAKILDA KEROGEENI TEKKIMISPROTSESSIST OSAVOTNUD MELANOIDIINIDE OLEMUSEST
}

\author{
L. Nappa \\ A. Fomina, \\ keemiateaduste doktor
}

Resümee

Diktüoneemakilda hüdrolüüsil pehmetes tingimustes (4-astmeline hüdrolüüs, hüdrolüüsi aeg à 2 tundi, happeks $5 \%$-line soulhape) identifitseeriti kolmanda astme hüdrolüsaadis glükoos, neljanda astme hüdrolüsaadis glükoos, arabinoos ja ramnoos. Kolmanda ja neljanda astme hüdrolüsaadis identifitseeriti ka glükoosamiin.

Aminohapete, suhkrute ja glükoosamiini olemasolu diktüoneemakilda hüdrolüsaadis lubab oletada, et diktüoneemakilda orgaanilise aine tekkeprotsessil etendasid olulist osa melanoidiinid, millede sünteesist võtsid osa nii hitiin ja selle fermentatiivne lagunemisprodukt glükoosamiin kui ka süsivesikute ja proteiinide fermentatiivsed lagunemisproduktid. Eesti NSV Teaduste Akadeemia
Keemia Instituut

\section{Saabus toimetusse}

8. II 1964

\section{ON THE NATURE OF MELANOIDINS TAKING PART IN THE FORMATION OF DICTYONEMA-SHALE KEROGEN}

\author{
L. Nappa, A. Fomina
}

\section{Summary}

At a hydrolysis in mild conditions (4-stage hydrolysis with a duration of 2 hours of each, acid - 5\% hydrochloric acid) of kerogen of dictyonema shale, in the hydrolysale of the 3rd stage glycose, and of the 4th stage glycose, arabinose and ramnose were identified. In the hydrolysate of the $3 \mathrm{rd}$ and 4 th stage, glycosamine was identified.

The presence of amino acids, sugars and glycosamine in the hydrolysate of dictyonema shale allows to suppose that in the formation process of organic matter in dictyonema shale, an important part was played by melanoidins, in whose synthesis not only chitin and its fermentative decomposition product, glycosamine, took part, but also the fermentative decomposition products of hydrocarbons and proteins.

\section{Academy of Sciences of the Estonian S.S.R., Institute of Chemistry}

Received

Feb. 8th, 1964 